\title{
Assessment of Bird Diversity and Abundance from Waste Disposal Sites in and Around Gubre Subcity, Wolkite Town, Southwestern Ethiopia
} Seyoum Kiros Meles ${ }^{1^{*}}$ and Bezawork Afework Bogale ${ }^{2}$

${ }^{1}$ Department of Biology, Wolkite University Wolkite, Ethiopia

${ }^{2}$ Departments of Zoological Sciences, Addis Ababa University, Addis Ababa, Ethiopia

*Corresponding author: Seyoum Kiros Meles, Department of Biology, Wolkite University Wolkite, Ethiopia, Tel: +0914555252; E-mail: kirosseyoum@yahoo.com

Received date: August 06, 2018; Accepted date: August 31, 2018; Published date: September 07, 2018

Copyright: (c) 2018 Meles SK, et al. This is an open access article distributed under the terms of the Creative Commons Attribution License, which permits unrestricted use, distribution and reproduction in any medium, provided the original author and source are credited.

\begin{abstract}
Waste disposal sites are predominantly used as feeding sites for generalist birds. The main objective of this study was to assess the diversity and abundance of birds from three waste disposal sites in and around Gubre sub city, Guraghe zone in 2017. Data were collected using point count techniques from 6:00-10:00 a.m. in the morning and 4:00-6:00 p.m. in the afternoon for three consecutive days each in three study sites. During this study, a total of 2566 birds belonging to 17 species, 7 Families and 6 Orders were recorded. From the 17 identified species of birds, 11 species each were from site I and III, while the remaining 7 species were recorded from site II. Among the seven identified families, Accipitridae was numerically the dominant family represented with 7 species, while Columbidae and Scopidae were the least dominant families represented with 1 species each. At species level, Hooded vulture (Necrosyrtes manachus) was the most abundant bird species. The total abundance of birds was significant (ANOVA result, $p=0.00$ ) difference among the three sites. In general, highest number of individual birds were counted in site I (1210) followed by site III (974) and site II (382). A significant difference in the abundance of birds between morning and afternoon was also observed (t- test, $\mathrm{p}=0.044$ ). Greater numbers of birds were counted in morning in all study sites (range: 93 in site II and 651 in site I). Site I was found to be with relatively higher value of species diversity $\left(H^{\prime}=1.2\right)$ than Site III $\left(H^{\prime}=1.01\right)$ and Site II $\left(H^{\prime}=0.90\right)$. In the study area, waste collectors, domestic dogs, cats and vehicles were considered as threats for waste dependent birds. More studies are required to make a complete list of available bird species in the study area.
\end{abstract}

Keywords: Abundance; Diversity; Threats; Waste disposal

\section{Introduction}

Globally, greater number of human population inhabits in and around urban areas, which accounts more than $50 \%$ of the global human populations [1]. According to Lee [2], urban expansion is still at an alarming rate particularly in the developing nations of Africa, Asia and Latin America. This urban expansion has a great impact on the survival, life history, demography and distributions of different species [3]. Moreover, in urban ecosystem, altered or modified habitats are found encompassing massive garbage disposals which have a considerable impact on biodiversity of that area [4]. In developing countries like Ethiopia, this problem is enhanced by continuous immigration of people from rural to urban centers [5].

Now days, different wildlife species are found outside of their natural habitats such as farmlands, grazing lands, in and around urban areas of several developing countries [6]. Among them, birds are the most known animals and a lot of bird species have been threatened as a result of habitat modifications [7,8]. Although urban development is considered as a detrimental factor to biodiversity, urban habitats play a great role in conservation of biodiversity [7].

Daha and Bhuju described that waste disposals sites have a great significant for the attraction of different wildlife species [9]. They are used as feeding sites for many wildlife species such as invertebrates, rodents, jackals, primate, bears and various birds particularly opportunistic and scavengers [10]. According to Chamberlain et al. the food presented in waste disposal site is very important during winter time and time of seasonal droughts [11]. The food obtained from waste disposal sites has many advantages. It helps to improve survival rate and body condition, enhance reproductive performance, reduces cost of feeding time, to minimize risk of migration, predation and extinctions particularly for endangered species. Thus, ecological and biological processes of many species are regulated by those human generated food items [12]. However, the reduction of food availability in waste disposal sites may also have a negative impact such as shifting in feeding behaviors and other costs [13].

Birds are well known class of organisms which have an ecological role in both natural and modified ecosystems. They have a great role in ecological functioning and process i.e. bioindicator of pollution, are agent's nutrient recycling and plant gene flow through seed dispersal and pollination, helps to minimize the levels of disposable wastes and regulate population of harmful insects and other pests [14]. According to Sethy et al. [15], assessment of bird community is important tool for biodiversity conservation and identifications of conservation actions in modified habitats. Having knowledge on diversity and composition of bird communities is also crucial to describe the health status the local ecosystem or regional landscapes for bird conservations.

In most African countries including Ethiopia, avian study, conservation and protection efforts are mainly focused on protected areas such as national parks. But, exploration and conservation of birds in urban areas particularly in waste disposal sites are neglected. According to Aerts et al. Aynalem and Bekele and Areaya et al. birds are one of the key components of global biodiversity, but there is still 
Citation: Meles SK, Bogale BA (2018) Assessment of Bird Diversity and Abundance from Waste Disposal Sites in and Around Gubre Subcity,

Page 2 of 7

knowledge gab/logical information is not available on bird diversity and abundances in several localities including the present study area [17-19]. To the best of our knowledge, no research has been done so far in Guber sub city, Wolkite particularly from waste disposal sites in order to know diversity and abundance of birds. In view of this, the present investigation could generate substantial information regarding the diversity and relative abundance of birds from waste disposal sites.

\section{Material and Methods}

\section{Study area}

The study was carried out in and around Gubre sub city, Wolkite, Guraghe zone (Figure 1). Gubre sub city is located at about $12 \mathrm{~km}$ away from Wolkite town in South West direction. Wolkite town is the capital city of Gurage zone located at a distance of $337 \mathrm{~km}$ from Hawassa (capital city of Southern Nations, Nationalities and Peoples Region) and $158 \mathrm{~km}$ away from South West of Addis Ababa. The geographical location of the town is approximately $8033^{\prime} \mathrm{N}$ latitude and $37059^{\prime} \mathrm{E}$ longitude. The average elevation of the town is about $1870 \mathrm{~m}$ above sea level. The mean annual temperature of the zone ranges between $13-300 \mathrm{c}$ with annual average temperature of 320c. The town has weynadega climatic condition with the mean annual rain fall ranges $600-1600 \mathrm{~mm}$. According to 2007 population census, the total population of Wolkite town was about 43,000 with (Male=22,360 and Female $=20,640$ ). The population is multi-ethnic, the Gurage constituting the majority [20].

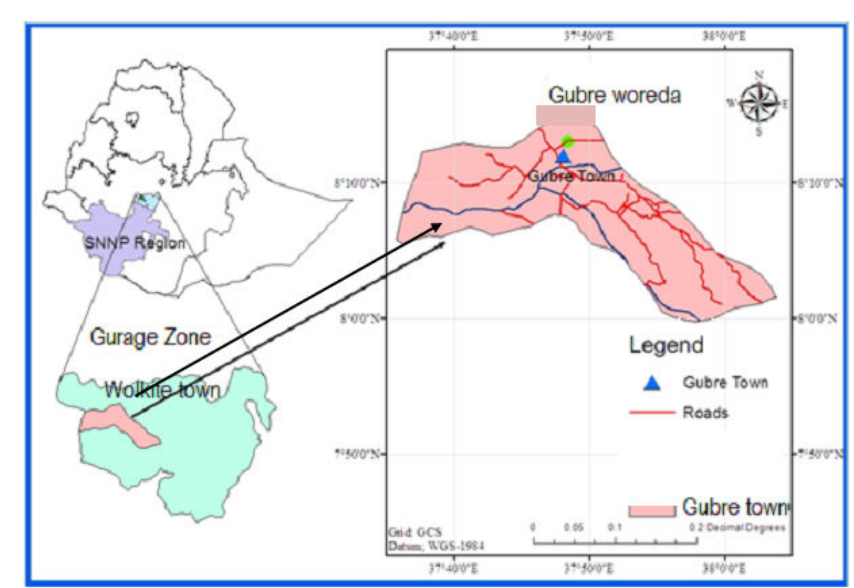

Figure 1: Location map of the study area (Source: Ayele, [21]).

In this study, three waste disposal sites were purposively selected named as site I, II and III respectively (Figure 2a, $2 \mathrm{~b}$ and 2c) based on the presence of waste temporally or permanently, water, forests and proximate or distant to road/human settlements.

Site I: It is found at the edge of forest areas around seven and five kilometers away from Wolkite town and Gubre sub city respectively. This is a permanent waste disposal site, which serves as a main dumping site for both of the main town (Wolkite) and Gubre sub city. Cordia africana and Eucalyptus plants are the two main plant species surrounding this dumping site. At the margin of this site stagnant as well as polluted water is also found. Different types of wastes are deposited into this site such as plastics, wood products, carrions, bones, scraps of meat and various unwanted fruits.

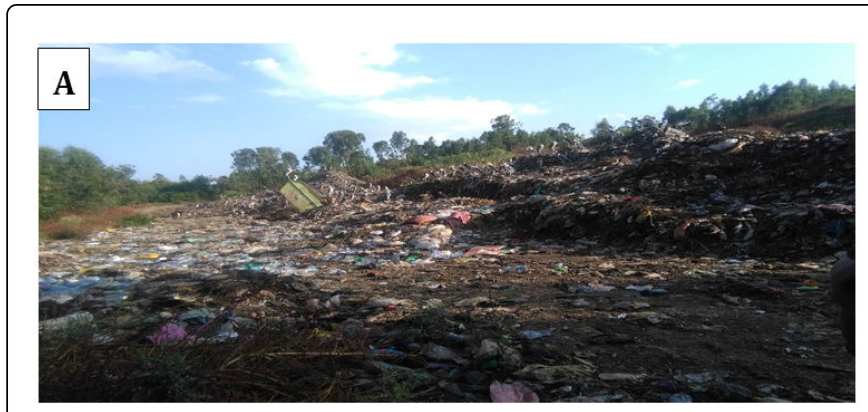

Figure 2a: Site I: a permanent waste disposal site at the edge of forest area.

Site II: This is a type of temporal waste disposal site which is located at the center of the Gubre sub city at a distance of five kilometers from site I. This site is also found in proximate to the main road of the Gubre subcity and human settlements. The type of waste deposited into this site includes plastics, parts of meat like offal, skin, bones and scraps through illegally slaughtered practices.

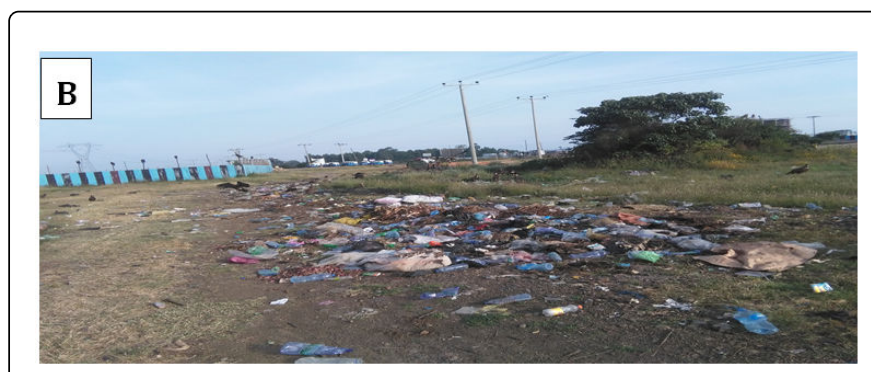

Figure 2b: Site II: A temporally waste disposal site at the center of the Gubre subcity.

Site III: This site is found at the edge of the Gubre subcity. It is located at a distance of approximately $7.5 \mathrm{~km}$ from site I and $2.5 \mathrm{~km}$ from site II. Eucalyptus and Acacia species are the main plant species found around this site. Below this site a large river which is known as Gubre river is found in which the local residents utilizes for washing clothes and cars, drinking for livestock and bathing for themselves. This site encompasses both the abattoir sites whose discarded wastes were deposited into Small River and the surrounding meat enterprises/ activities engaged in meat trades areas. The type of waste found in this site includes offal and piles of bones.

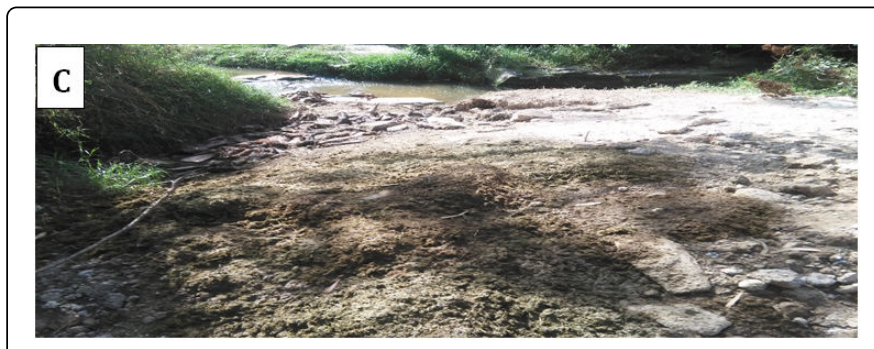

Figure 2c: Site III: A permanent waste disposal site at the edge of Gubre subcity. 


\section{Data Collection}

Field data were conducted from three waste disposal sites in November, 2017 for three consecutive days for each site. Before data collection a preliminary survey was conducted to characterize the location of the waste disposal sites. Then data were collected using point count techniques by selecting an appropriate locations/ observation points to make sure maximum chances of observations following the method of Sidra et al. [22]. During this study a total of five point stations were selected; two at site I and III each and one at site II depending on the size of the waste disposal site and maximum distance where observation of birds possible.

Field observations were started at 6:00-10:00 a.m. in the early morning and at 4:00-6:00 p.m. in the afternoon when birds are active. During an observation: list of species with their approximate population sizes, activities and threats were recorded. The available birds were observed by naked eye and using binoculars and then bird species were taxonomically classified using bird guide book of Redman et al. and other standardized references [23].

\section{Data Analysis}

Data were arranged, organized and entered into Microsoft excel for analysis. Shannon-Weiner diversity index $\left(\mathrm{H}^{\prime}\right)$ was used to analyze bird diversity of the study area. It was calculated as:

$$
H^{\prime}=-\sum_{i=1}^{s}\left(\frac{n i}{N}\right) \times \ln \left(\frac{n i}{N}\right)
$$

Where $H^{\prime}=$ index of species diversity, ni is the number of individuals in a species, $\mathrm{S}$ is the total number of species, also called species richness, $\mathrm{N}$ is the total number of individuals.

Evenness index ( $\left.J^{\prime}\right)$ was calculated by following the equation.

$$
J^{\prime}=\frac{H^{\prime}}{\ln S}
$$

Where: $\mathrm{H}=$ Shannon Weiner diversity index and $\mathrm{S}=$ Number of species

Richness index (D) was calculated by the following equation

$$
D=\frac{S-1}{\ln N}
$$

Where, $\mathrm{D}=$ Richness index, $\mathrm{S}=$ Total number of species and $\mathrm{N}=$ Total number of individuals

Relative abundance of bird species was determined using encounter rates that give basic ordinal scales of abundance (abundant, common, frequent, uncommon and rare) [18]. Encounter rate for each species was calculated by dividing the number of birds recorded by the number of hours spent searching, giving a figure of birds per hour for each species. The abundance categories (the number of individuals per 100 field hours) were: $<0.1,0.1-2.0,2.1-10.0,10.1-40.0$ and $>40$. For each category, the following abundance score is given: 1 (rare), 2 (uncommon), 3 (frequent), 4 (common) and 5 (abundant) respectively.

Moreover to understand bird community similarity among sites, Sorensen's coefficient was applied [19]. It was calculated as:

$$
S=\frac{3 c}{A+B+C}
$$

Where $\mathrm{S}=$ Sorenson's Coefficient, $\mathrm{c}$ is the number of species the three communities have in common, $\mathrm{A}$ is the total number of species found in community A, B is the total number of species found in community
$\mathrm{B}$ and $\mathrm{C}$ is the total number of species found in community $\mathrm{C}$. Sorenson's coefficient gives a value between 0 and 1, the closer the value is to 1 , the more the communities have in common.

To check the presence of variation in bird abundance between morning and afternoon sessions, T-test was applied. Moreover, to check the presence of variation in bird abundance among sites, One Way ANOVA was used using SPSS version 16 computer software. Graphs were drawn by using Microsoft offices excel 2007 computer software.

\section{Result}

\section{Species composition of birds}

During the present study a total of 17 species of bird belonging to 7 Families and 6 Orders were recorded from the study area. Family Accipitridae was numerically the dominant family represented with 7 species which accounts $41.2 \%$, of identified species, while Columbidae and Scopidae were the least dominant families represented with 1 species each (Table 1). At species level, Hooded vulture was the most abundant species, while Hamerkop, White stork and Yellow billed duck

\begin{tabular}{|c|c|c|c|}
\hline Common name & Scientific name & Family & Order \\
\hline African hawk eagle & Aquila spilogaster & Accipitridae & Acipcitriformes \\
\hline Black kite & Milvus migrans & & \\
\hline Hooded vulture & $\begin{array}{l}\text { Necrosyrtes } \\
\text { manachus }\end{array}$ & & \\
\hline Rueppell's Griffon & Gyps rueppellii & & \\
\hline Tawny eagle & Aquila rapax & & \\
\hline $\begin{array}{l}\text { White-backed } \\
\text { Vulture }\end{array}$ & Gyps africanus & & \\
\hline Yellow billed kite & Milvus aegyptius & & \\
\hline Egyptian goose & Alopochen aegyptiaca & Anatidae & Anseriformes \\
\hline Yellow billed duck & Anas undulata & & \\
\hline Marabou stork & $\begin{array}{l}\text { Leptoptilos } \\
\text { crumeniferus }\end{array}$ & Coconiidae & Ciconiformes \\
\hline White stork & Ciconia ciconia & & \\
\hline Ring necked dove & Streptopelia capicola & Columbidae & $\begin{array}{c}\text { Columbiforme } \\
\mathrm{s}\end{array}$ \\
\hline Fan tailed raven & Corvus rhipidurus & Corvidae & Passeriformes \\
\hline Thick billed raven & Corvus crassirostris & & \\
\hline Hadada ibis & Bostrychia hagedash & $\begin{array}{c}\text { Threskiornithida } \\
\mathrm{e}\end{array}$ & $\begin{array}{c}\text { Pelecaniforme } \\
\mathrm{s}\end{array}$ \\
\hline Wattled ibis & $\begin{array}{l}\text { Bostrychia } \\
\text { carunculata }\end{array}$ & & \\
\hline Hamerkop & Scopus umbretta & Scopidae & \\
\hline
\end{tabular}
were categorized under rare species. Two near endemic birds were recorded from the study sites named as Thick billed raven and Wattled ibis which contributing $11.76 \%$ of the identified species.

Table 1: List of bird species identified from the study area. 
Citation: Meles SK, Bogale BA (2018) Assessment of Bird Diversity and Abundance from Waste Disposal Sites in and Around Gubre Subcity, Wolkite Town, Southwestern Ethiopia . Int J Waste ResouR 8: 354. doi:10.4172/2252-5211.1000354

Page 4 of 7

\section{Distribution and abundance of birds}

From the 17 species of birds identified during the study period, 11 bird species were recorded from site I and III each, while the rest 7 species were recorded from site II. Among these, Hooded vulture, White-backed Vulture, Yellow billed kite and Thick billed raven were found in all sites and contributing around $72.48 \%$ of the total bird abundance of the study area (Table 2).

\begin{tabular}{|c|c|c|c|c|}
\hline Common name & Scientific name & $\begin{array}{c}\text { Site } \\
\text { I }\end{array}$ & $\begin{array}{c}\text { Site } \\
\text { II }\end{array}$ & $\begin{array}{c}\text { Site } \\
\text { III }\end{array}$ \\
\hline African hawk eagle & Aquila spilogaster & + & - & - \\
\hline Black kite & Milvus migrans & - & + & + \\
\hline Hooded vulture & Necrosyrtes manachus & ++ & ++ & ++ \\
\hline Rueppell's Griffon & Gyps rueppellii & + & - & - \\
\hline Tawny eagle & Aquila rapax & - & + & + \\
\hline White-backed Vulture & Gyps africanus & ++ & ++ & ++ \\
\hline Yellow billed kite & Milvus aegyptius & ++ & ++ & ++ \\
\hline Egyptian goose & Alopochen aegyptiaca & + & - & + \\
\hline Yellow billed duck & Anas undulata & - & - & + \\
\hline Marabou stork & Leptoptilos crumeniferus & + & - & + \\
\hline White stork & Ciconia ciconia & - & - & + \\
\hline Ring necked dove & Streptopelia capicola & + & - & - \\
\hline Fan tailed raven & Corvus rhipidurus & - & + & - \\
\hline Thick billed raven & Corvus crassirostris & ++ & ++ & ++ \\
\hline Hadada ibis & Bostrychia hagedash & + & - & - \\
\hline Wattled ibis & Bostrychia carunculata & - & - & + \\
\hline Hamerkop & Scopus umbretta & + & - & - \\
\hline & Total & 11 & 7 & 11 \\
\hline & & + & + \\
\hline
\end{tabular}

Table 2: Distribution of bird species in the study area.

+ denote the species present, - denote the species absent, ++ denote the species common to the three sites

In the present investigation, a total of 2566 birds were counted from the three sites. Out of this, 1210 birds from site I, 382 and 974 birds from site II and III respectively. The total abundance of birds showed significant (ANOVA result, $\mathrm{p}=0.00$ ) differences between the three sites. The highest bird abundance was recorded in site I, while the lowest was in site II (Figure 3).

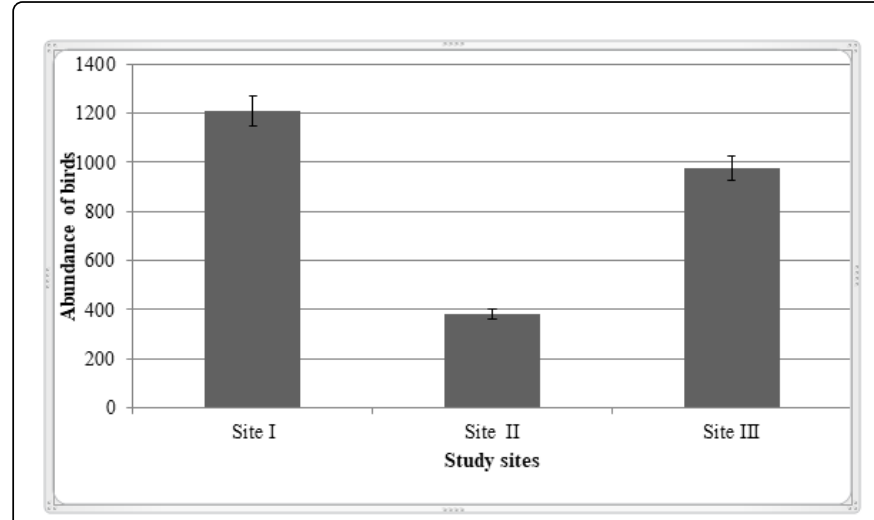

Figure 3: Spatial variation in the abundance of birds of the study sites.

A significant difference in abundance of bird was also observed between morning and afternoon sessions ( $\mathrm{t}-$ test, $\mathrm{p}=0.044$ ). Highest numbers of birds were counted in morning hours in all study sites (Figure 4). The total number of birds observed ranged between 93 individual in site II in afternoon hours and 651 individuals in site I in the morning time.

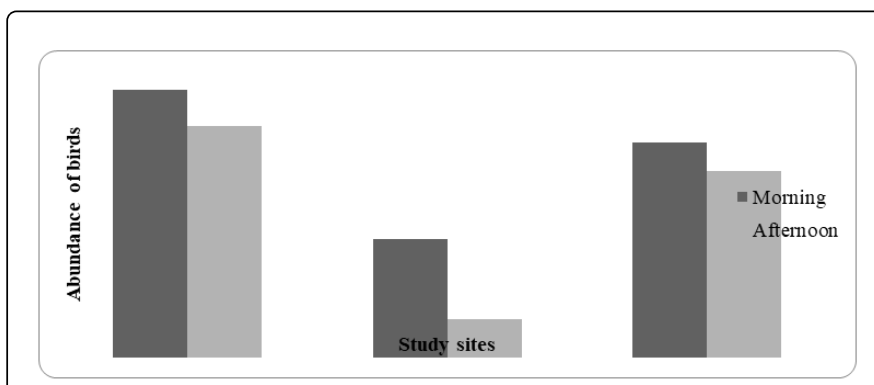

Figure 4: Temporal variation in abundance of birds of the study sites.

\section{Species diversity and community similarity}

Site I showed slightly higher values of species diversity $\left(H^{\prime}=1.2\right)$ than site II and III. Evenness index show slightly variation was found between site II and III, indicating that these two sites have less even distribution of birds (Table 3 ). The overall community similarity of the three study sites was low $(\mathrm{S}=0.413)$.

\begin{tabular}{|c|c|c|c|c|c|}
\hline Sites & S & N & D' & J' & H' \\
\hline Site I & 11 & 1210 & 1.41 & 0.50 & 1.2 \\
\hline Site II & 7 & 382 & 1.01 & 0.46 & 0.90 \\
\hline Site III & 11 & 974 & 1.45 & 0.42 & 1.01 \\
\hline
\end{tabular}

Table 3: Over all diversity, evenness and species richness indexes birds of the study sites.

Where $(\mathrm{S})=$ total number of species, $(\mathrm{N})=$ total number of individuals, $\left(D^{\prime}\right)=$ species richness index, $\left(J^{\prime}\right)=$ Evenness index and $\left(H^{\prime}\right)=$ Shannon diversity 
Page 5 of 7

\section{Relative abundance of birds}

In this study, based on relative abundance scores, Hooded vulture was an abundant species, while Hamerkop, White stork and Yellow billed duck were grouped under rare species (Table 4).

\begin{tabular}{|c|c|c|c|c|c|c|}
\hline $\begin{array}{l}\text { Species } \\
\text { name }\end{array}$ & Site I & Site II & Site III & Total & ER & Ordinal scale \\
\hline $\begin{array}{c}\text { African } \\
\text { Hawk Eagle }\end{array}$ & 4 & 0 & 0 & 4 & 0.14 & Uncommon \\
\hline Black Kite & 0 & 14 & 14 & 28 & 0.96 & Uncommon \\
\hline $\begin{array}{l}\text { Hooded } \\
\text { Vulture }\end{array}$ & 657 & 294 & 740 & 1691 & 57.99 & Abundant \\
\hline $\begin{array}{l}\text { Rueppell's } \\
\text { Griffon }\end{array}$ & 10 & 0 & 0 & 10 & 0.34 & Uncommon \\
\hline Tawny Eagle & 0 & 27 & 40 & 67 & 2.29 & Frequent \\
\hline $\begin{array}{l}\text { White- } \\
\text { Backed } \\
\text { Vulture }\end{array}$ & 29 & 12 & 25 & 66 & 2.26 & Frequent \\
\hline $\begin{array}{l}\text { Yellow Billed } \\
\text { Kite }\end{array}$ & 29 & 28 & 34 & 91 & 3.12 & Frequent \\
\hline $\begin{array}{l}\text { Egyptian } \\
\text { Goose }\end{array}$ & 12 & 0 & 11 & 23 & 0.79 & Uncommon \\
\hline $\begin{array}{l}\text { Yellow Billed } \\
\text { Duck }\end{array}$ & 0 & 0 & 2 & 2 & 0.07 & Rare \\
\hline $\begin{array}{l}\text { Marabou } \\
\text { Stork }\end{array}$ & 431 & 0 & 69 & 500 & 17.15 & Common \\
\hline White Stork & 0 & 0 & 2 & 2 & 0.07 & Rare \\
\hline $\begin{array}{l}\text { Ring Necked } \\
\text { Dove }\end{array}$ & 24 & 0 & 0 & 24 & 0.82 & Uncommon \\
\hline $\begin{array}{c}\text { Fan Tailed } \\
\text { Raven }\end{array}$ & 0 & 3 & 0 & 3 & 0.1 & Uncommon \\
\hline $\begin{array}{l}\text { Thick Billed } \\
\text { Raven }\end{array}$ & 2 & 4 & 6 & 12 & 0.41 & Uncommon \\
\hline Hadada Ibis & 10 & 0 & 0 & 10 & 0.34 & Uncommon \\
\hline Wattled Ibis & 0 & 0 & 31 & 31 & 1.06 & Uncommon \\
\hline Hamerkop & 2 & 0 & 0 & 2 & 0.07 & Rare \\
\hline
\end{tabular}

Table 4: Relative abundance of bird species.

Where ER=Encounter Rate

\section{Discussion}

Exploration of birds' at micro habitats is very important to understand the carrying capacity of the area in supporting of birds. Bird's species richness and abundances are directly or indirectly affected by anthropogenic factors [24]. Waste disposal sites are set among the primary modified feeding sites for many birds created by humans [25]. These sites not only provided organic food sources but also they harbors different prey species like invertebrates, small mammals and birds used as a food source for different predator species [26].
The present study in Gubre subcity, Wolkite town showed that site I and III supports a considerable number of birds as compared to site II. This might be related with the, permanence, abundances and availability food required in these sites that can support more species. This is in line with result of Mulualem et al. food availability is considered as a primary driver of birds' existence [27]. An area which has an abundant of food resources can support greater number of individuals or species of birds [28].

In the study area different bird species such as carnivores/ scavengers and aquatic birds particularly from site I and III were recorded. This is associated with the location these waste disposal sites as they are found around aquatic and forest ecosystems. Hence, they might be created food opportunities for non-scavenger birds such as Egyptian goose, Hadada ibis and Ring necked doves. This is in agreement with report of Plaza and Lambertucci [26] where, in waste disposal sites different food items are found such fish, meat, chicken, offal, eggs, seeds, cheese and fruits are which is consumed by different birds according to their feeding habits. In addition to this, the presence of water and tree around the waste disposal site may also provide additional ecological needs for theses waste site dependent birds. Although, birds are primarily used waste disposal sites for feeding purposes, the surrounding habitats are also used for other ecological needs and processes [24].

The species composition of birds (17 species) reported in present study was lower than from the report of Hibste $(21$ species) in Addis Ababa Abattoirs Enterprise, Ethiopia but, higher than from the report of Mulualem et al. (6 species) in Ashewa local vulture restaurant in Dire Dawa, Ethiopia [27,29]. This variation in species composition might be related with availability of food presented and the degree of threats/disturbances found in the area, duration of the study period and other ecological needs surrounding the area.

Among the recorded scavengers, Rupples vulture and Marabou stork were not presented in site II. This might be associated with the resistance/tolerance of these species towards anthropogenic and other disturbances. Navarro et al. also stated different species have different degree of responses to depend upon the degree and the type of disturbance presented [30]. Thus, large raptors are very sensitive to anthropogenic or other disturbances than other birds [31].

In all study sites, Hooded Vultures was numerically the dominant species compared to other bird species. This is in line with Mulualem et al. occurrences of high population size of this bird might be associated with resistances towards disturbances and generalist feeding habit of the species as they feeds on offal, food scraps and other locally dumped food sources [27].

During this study, less numbers of individual birds were counted at afternoon sessions. This might be associated with food limitations as the wastes were usually dumped in the morning hours. Moreover, the remaining food scarps might also be consumed by dogs as their numbers were increased from morning to middays. Jokimaki et al. also stated food is a major limiting factor that limits the number of bird's invasion at particular area at a particular time [32]. In addition to shift in dietary preferences, distribution and quantity of food waste is likely to influence the carrying capacity, behaviour, and habitat use of wildlife including birds [26].

During this study, food competition among storks, vultures and eagles was frequently observed. Intra and interspecific competitions among species and individuals in waste disposal sites are common including fighting and stealing of food [33]. As a result, several species 
Citation: Meles SK, Bogale BA (2018) Assessment of Bird Diversity and Abundance from Waste Disposal Sites in and Around Gubre Subcity,

Page 6 of 7

are take advantage or develop alternative foraging strategies to withstand the competition levels with other individuals [26]. According to Arriagada et al. daily activity patterns of birds, related to foraging and territorial displays, are affected by biotic variables such as competition, predation, food availability, habitat type and phylogenetic constraints and abiotic variables such as climatic conditions [34].

In the study area, the birds were threatened by anthropogenic factors, dogs, cats and vehicle disturbances (Figures 5 and 6). These might be affected the survival rate, species composition and abundance of birds. For instance, less number of species and individuals were counted in site II as this site was more exposed to disturbances than site I and III. According to Novaes and Cintra, species richness and abundances of birds are determined by distance of the dumping sites towards human settlements and other activities [35].

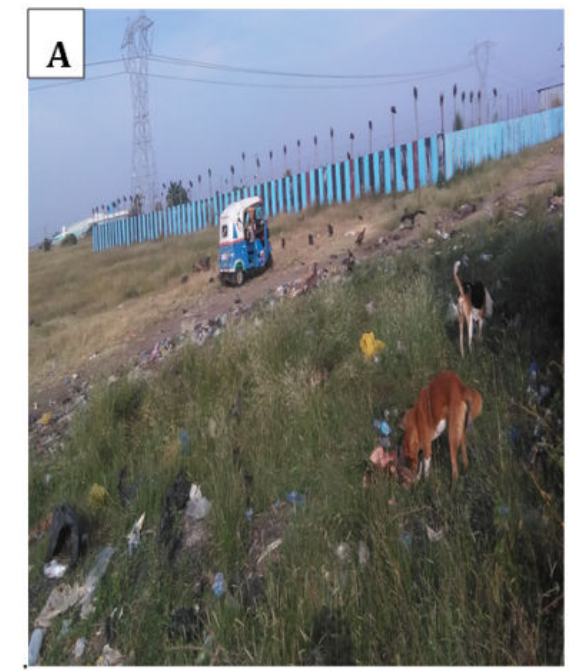

Figure 5: Dogs and vehicles.

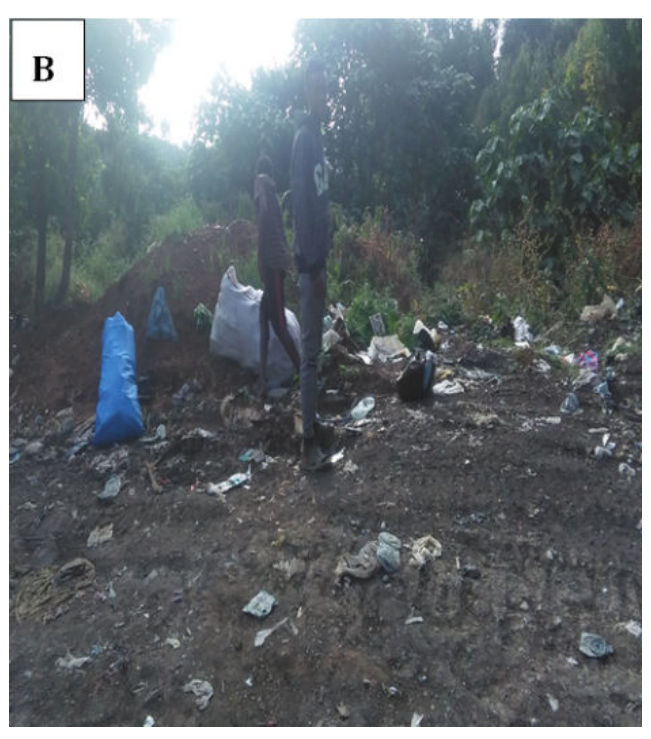

Figure 6: Human activity (Waste collectors).
Benitez-Lopez et al. also found that bird population size is decreased with proximity of roads [36]. The presence of free-ranging domestic dogs and cats in garbage dumps have been documented somewhere else [26,37], which might be affected bird feeding and other activities. Loss et al. reported cat predation on juvenile birds is one of the main causes of bird mortality in urban areas [38]. Disturbance by dogs can also cause energetic loss when it results in an evasive response, increased vigilance, or lost foraging opportunities [37]. Human can also affected birds in waste disposal sites though physical disturbance such approaching or walking through their feeding and perching sites [10]. According to Mulualem et al. waste collectors and free ranging domestic dogs are the major threatened factors which interrupt the normal feeding activity of birds in dumping sites [27]. Despite of the fact that the conditions are not favorable for the birds, the waste sites harbored substantial number of species [24].

\section{Conclusion}

During the present study various bird species were recorded from the waste disposal sites. From the present study it is clear that, the bird species composition and abundance varied spatially and temporally. Bird species abundance was higher in some sites and during morning hour related to the variation in food items, degree of threat presented and the location of site as well. Among the seven families identified, Accipitridae was numerically the dominant family with seven representative species with scavenging mode of feeding. This indicated that in all sites, part of meat such as offal, bones and other dead organisms are readily available for these species. In addition, from the seventeen identified bird species, Hooded vulture (Necrosyrtes manachus) was numerically the most dominant bird species indicating an adaption of the species to different types of food. Waste collector, domestic dogs, cats and vehicles were observed in the study area causing major threats to the bird's activity patterns such as feeding. Thus, it is necessary to change the sites (particularly site II) in to other appropriate locations/ remote areas) to reduce the threats and to enhance survival rate of the birds.

\section{Recommendation}

With respect to conservation measures, these findings stress the importance of waste disposal sites supporting different species of birds. Based on the results which are obtained during the study period, the following recommendations are made.

Since, the waste disposal sites are located around roads, human settlements, aquatic habitats and open areas; there is a need to changes these locations in to other appropriate locations to minimize the risk of danger to the birds, water pollution and human health as well.

These dumping sites harbors different birds including endemic birds, thus, conservation and management strategies are needed.

Waste disposal sites as compared with other habitat of birds, receive less attentions by researchers and wild life managers, therefore, developing positive attitudes towards these areas are very essential as one part of biodiversity conservations.

Since, miscellaneous wastes are found in the study sites, it is better to set separately as organic and non-organic wastes to reduce energy cost and threats to birds. 
Citation: Meles SK, Bogale BA (2018) Assessment of Bird Diversity and Abundance from Waste Disposal Sites in and Around Gubre Subcity, Wolkite Town, Southwestern Ethiopia . Int J Waste ResouR 8: 354. doi:10.4172/2252-5211.1000354

Page 7 of 7

\section{References}

1. United Nations (2007) World urbanization prospects: The 2007 revision population database. United Nations, New York.

2. Lee KN (2007) An urbanizing world. In: Starke L (editor) State of the World 2007: Our urban future. WW Norton and Company, New York. Pp: 3-21.

3. Grimm NB, Faeth SH, Golubiewski NE, Redman CL, Wu J, et al. (2008) Global change and the ecology of cities. Science 319: 756-760.

4. Pickett ST, Cadenasso ML, Grove JM, Boone CG, Groffmann PM, et al. (2011) Urban ecological systems: Scientific foundations and a decade of progress. J Envi Mana 92: 331-362.

5. Montgomery MR (2008) The urban transformation of the developing world. Science 319: 761-764.

6. Bolwig S, Pomeroy D, Tushabe H, Mushabe D (2006) Crops, trees, and birds: biodiversity change under agricultural intensifiation in Uganda's farmed landscapes. Danish J Geo 106: 115-130.

7. Evans KL, Newson SE, Gaston KJ (2009) Habitat influences on urban avian assemblages. Ibis, 151:19-39.

8. Strohbach M, Haase D, Kabisch N (2009) Birds and the city: Urban biodiversity, land use and socioeconomics. Ecology and Society 14: 31-45.

9. Daha RB, Bhuj RD (2008) Bird mobility and their habitat at Tribhuvan International Airport, Kathmandu. Nep J Sci Tech 9: 119-130.

10. Clucas B, Marzluff MJ (2011) Attitudes and actions toward birds in urban areas: Human cultural differences influence bird behavior. Auk 129: 1-9.

11. Chamberlain DE, Cannon AR, Toms MP, Leech DI, Hatchwell BJ, et al (2009) Avian productivity in urban landscapes: A review and metaanalysis. Ibis 151: 1-18.

12. Oro D, Genovart M, Tavecchia G, Fowler MS, Martınez-Abrain A (2013) Ecological and evolutionary implications of food subsidies from humans. Ecol Lett 16: 1501-1514.

13. Duhem C, Vidal E, Legrand J, Tatoni T (2003) Opportunistic feeding responses of the Yellow-legged Gull Larus michahellis to accessibility of refuse dumps: The gulls adjust their diet composition and diversity according to refuse dump accessibility. Bird Study 50: 61-67.

14. Sekercioglu $\mathrm{CH}$ (2006) Increasing awareness of avian ecological function. Tren ecol evol 21: 8.

15. Sethy J, Sama D, Sethi S, Baral B, Jena S, et al. (2015) Species diversity and abundance of birds in and around North Orissa University, Takatpur Baripada, Mayurbhanj, Odisha. Inte J Innov Rese Scie Eng Tech 4: 1-12.

16. Rodrigues AS, Akçakaya HR, Andelman SJ, Bakarr MI, Boitani L, et al. (2004) Global gap analysis: priority regions for expanding the global protected-area network. Bio Science 54: 1092-1100.

17. Aerts R, Lerouge F, November E, Lens L, Hermy M, et al. (2008) Land rehabilitation and the conservation of birds in a degraded Afromontane landscape in northern Ethiopia. Biodi Conser 17: 53-69.

18. Aynalem S, Bekele A (2008) Species composition, relative abundance and distribution of bird fauna of riverine and wetland habitats of Infranz and Yiganda at southern tip of Lake Tana, Ethiopia. Trop Ecol 49: 199-209.

19. Areaya H, Yonas M, Haileselasie TH ( 2013) Community composition and abundance of residential birds in selected church forests, Tigray Region, Northern Ethiopia. Scientific Research and Essays 8: 1038-1047.

20. Ahmedin H (2013) Assessment on awareness of and views about solid waste management among high school students in Gurage zone, Wolkite town, Ethiopia. MS.c Thesis, University of Addis Ababa, Ethiopia Pp: 99.
21. Ayele A (2012) Integrated geophysical and geotechnical investigations for the building site characterization of Wolkite University, Gubre, Wolkite, Ethiopia. M.Sc. Thesis, university Addis Ababa, Ethiopia Pp: 111.

22. Sidra S, Ali Z, Chaudhry NM (2013) Avian diversity at new campus of Punjab University in relation to land use change. Pakis J Zool 45: 1069-1082.

23. Redman N, Stevenson T, Fanshawe J (2011) Birds of the Horn of Africa: Ethiopia, Eritrea, Djibouti, Somalia, and Socotra. 2nd edition, Christopher Helm, London, UK. Pp: 460.

24. Mehra SP, Mehra S, Uddin M, Verma V, Sharma H (2017) Waste as a Resource for Avifauna: Review and Survey of the Avifaunal Composition in and around Waste Dumping Sites and Sewage Water Collection Sites (India). Int J Waste Resour 7: 289.

25. Birdlife International (2014) Waste management: Best practices to conserve migrating soaring birds in the rift valley-red sea flyway.

26. Plaza PI, Lambertucci SA (2017) How are garbage dumps impacting vertebrate demography, health, and conservation? Glo Ecol Conser 12: 9-20.

27. Mulualem G, Ayalew S, Tesfahunage W (2016) Abundance and activity pattern of avifauna in Ashewa Local Vulture Restaurant, Dire Dawa Eastern Ethiopia. Int J Avian Wildlife Biol 1: 00005.

28. Taylor L, Taylor C, Davis A (2013) The impact of urbanization on avian species: The inextricable link between people and birds. Urban Ecosystem 16: 481-498.

29. Hibste H (2007) Species composition, abundance and activity pattern of birds of Addis Ababa Abattoirs Enterprise. MSc. Thesis, University of Addis Ababa, Ethiopia p: 99.

30. Navarro J, Grémillet D, Ramirez FJ, Afán I, Bouten W, et al. (2017) Shifting individual habitat specialization of a successful predator living in anthropogenic landscapes. Mar Ecol Prog Ser. Theme Section. Advance View p: 9.

31. Seress G Liker A (2015) Habitat urbanization and its effects on birds. Acta Zool Acad Scie Hung 61: 373-408

32. Jokimäki ML, Hakkarainen H, Huhta E, Inki K, Suorsa P, et al. (2009) Urbanization and stability of a bird community in winter. Ecoscience 16 502-507.

33. Annorbah NN, Holbech LH (2012) Relative abundance, agonistic behaviour, and resource partitioning among three scavenging bird species in Ghana. Malimbus 34: 1-8.

34. Arriagada RR, Jime JE, Rozzi R (2015) Daily patterns of activity of passerine birds in a Magellanic sub-Antarctic forest at Omora Park (55oc), Cape Horn Biosphere Reserve, and Chile. Polar Biol 38: 401-411.

35. Novaes WG, Cintra R (2013) Factors Influencing the Selection of Communal Roost Sites by the Black Vulture Coragyps Atratus (Aves: Cathartidae) in an Urban Area in Central Amazon. Zool Curitiba 30: 607-614

36. Benítez-López A, Alkemade R, Verweij PA (2010) The impacts of roads and other infrastructure on mammal and bird populations: A metaanalysis. Biol Conser 143: 1307-1316.

37. Forrest A (2006) Effects of dog leash laws and habitat type on avian and small mammal communities in urban parks. Urban Ecol 9: 51-66.

38. Loss SR, Will T, Marra PP (2013) The impact of free-ranging domestic cats on wildlife of the United States. Nature Communications 4: 1396. 